\title{
Historical linguistics and Philippine hunter-gatherers
}

\author{
Lawrence A. Reid \\ University of Hawai $i$ \\ International Institute of Asian Studies, University of Leiden
}

This paper addresses several topics with reference to Philippine hunter-gatherer groups that are relevant to an understanding of their relationships with non-hunter-gatherer groups and their significance for historical linguistics. Section 1 first provides a discussion of the demographic ranges of the extant Negrito groups. In section 2, different views as to the time depth of the prehistoric relationship of Negrito groups with in-migrating Neolithic Austronesian speakers to the Philippines will be evaluated. Section 3 then deals with the patterns of their relationship with farmers, specifically the competing patterns of close association with and avoidance of farmers, as revealed from the types of linguistic relationship that hold between the two groups, and in section 4 evidence for retention of a non-Austronesian substratum in the languages of Negrito groups will be discussed. Finally, in section 5, the coastal/seafaring Negritos of northeast Luzon and the linguistic influence they have had on farmer populations of the area will be described. ${ }^{1}$

* It gives me great pleasure to be able to present this paper to Howard McKaughan, truly one of the great gentlemen and scholars of our time. It was Howard who first escorted me into the village of Guinaang, Bontoc, when I began my research there in 1959 as a neophyte member of SIL, and who over the next four years acted as friend, advisor, and mentor as I considered doing a graduate program in linguistics. It was he who invited me to follow him in 1963 as one of the first graduate students in the newly formed Department of Linguistics at the University of Hawai' $i$ (UH), to which he had been appointed as acting chair. Over the next three years, Howard guided me to the completion of MA and PhD programs, and four years later extended an invitation to me to spend a year at the then newly formed Pacific and Asian Linguistics Institute, of which he was the Director, to finish the preparation of a Bontok-English dictionary with National Science Foundation funding (eventually appearing as Reid 1976). This was a visit that turned into a permanent appointment and more than thirty years of tenure at UH, during which Howard gradually moved up the administrative ranks until he was acting chancellor of the University's Mānoa campus. Despite the great pressures on his time that his academic and administrative positions demanded of him, Howard was always available to discuss linguistic problems and to share the hospitality of his home and family with his students. There are not too many academics who upon hearing the woes of a young graduate student whose old car had just broken down would say, "The clutch needs replacing, Laurie. Come over to the house this weekend and I'll help you fix it." Which is what he did. His influence on my life extended far beyond what would normally be expected of an advisor. Without his wise guidance, my linguistic career might never have gotten off the ground.

1 This paper was originally presented to the symposium on Historical Linguistics and Hunter-Gatherer Populations in Global Perspective, Max Planck Institute for Evolutionary Anthropology, Leipzig, 10-12 August 2006.

Loren Billings \& Nelleke Goudswaard (eds.), Piakandatu ami Dr. Howard P. McKaughan, 6-_.

Manila: Linguistic Society of the Philippines and SIL Philippines, 2007. 


\section{HUNTER-GATHERER GROUPS IN THE PHILIPPINES}

In addition to the Negrito groups, who are traditionally all hunter-gatherers, there is one non-Negrito hunter-gatherer group reported for the Philippines who were also traditionally hunter-gatherers. These are the Tasaday, a group of formerly cave-dwelling Manobo, first reported in the early 1970s and frequently portrayed in the popular press as a hoax. The linguistic evidence for the authenticity of the Tasaday as a distinct ethnolinguistic group is irrefutable and has been dealt with in various papers (Reid 1992, 1996, 1997). This is the only case known in the Philippines where a formerly food-producing population is known to have acquired a huntergatherer subsistence secondarily, probably brought about by a small number of people escaping to the forest within the last two to three hundred years, to avoid some catastrophic epidemic. In recent years, the group has intermarried with neighboring farmers and has again adopted a farming lifestyle supplemented by gathering of forest products. Their similarity in many respects to the Mlabri of Laos and Thailand has been commented on in Reid (1997:193-195). The Tasaday will not be discussed further in this paper. Appendix A provides a listing of the known Negrito groups still speaking languages distinct from their non-Negrito neighbors in the Philippines, and the map in appendix B identifies the general locations where these Negrito languages are still spoken. It should be noted that the various Ayta groups in western Luzon are fairly closely related to one another, and that in the Bicol region of southeastern Luzon the Manide and Rinconada Agta have a number of distinct dialects. ${ }^{2}$ The same is true also of Atta and the Dumagat and other Agta groups of the eastern coastal areas of Luzon.

The names of Negrito groups which are of most interest, however, are those that reflect Proto-Extra-Formosan *qaRta(q) 'Negrito'; these terms include Agta, Atta, Arta, Alta, and Ayta, with the variant medial consonant depending on the reflex of the $* \mathrm{R}$ protophoneme. ${ }^{3}$ These names are of interest because the majority of Negrito groups use them to refer to themselves and to distinguish themselves from so-called farming

2 Headland (2002:26) also contains a table said to list thirty-three Negrito languages still spoken in the Philippines. A few problems exist with that table. First, only thirty-two groups are actually listed; second, two of the languages (Agta of Villaviciosa, Abra Province; Agta of Dicamay, Jones, Isabela Province) are listed as extinct. Current fieldwork by Jason Lobel, a doctoral candidate at the University of Hawai' $i$, suggests that several others in the Headland list may also no longer be spoken. These include Agta of Isarog, Camarines Sur Province (listed by Headland as nearly extinct), and so-called Ayta of Sorsogon Province. Sinauna (not listed by Headland) may also be extinct, as apparently also is Remontado Agta with which it is equated in the Ethnologue (Gordon 2005). Although there are large numbers of people identified as Negrito throughout the Bicol and Visayan areas, there are relatively few who still speak a language distinct from that of their neighbors. Lobel claims, moreover, that the groups that he has visited are no longer nomadic; all have lost their traditional lifestyle and live year-round in houses. Manide and Rinconada Agta are Lobel's terms (personal communication, 20 June 2006).

3 The following transcriptions (shown in italics) used in this paper represent deviations from the International Phonetic Alphabet (in square brackets): $y$ [j], $j[\mathrm{~d}]$; in addition, $N($ and $* \mathrm{~N})$ is a place-assimilating nasal consonant; capital letters in reconstructions (i.e., in forms preceded by an asterisk) - C, G, R, and T - are conventional symbols used in Austronesian historical linguistics, the exact phonetic values of which are often not fully agreed upon. In addition, a preceding equals sign indicates that the form is an enclitic. Finally, the following special abbreviations are used in this paper. ALTN: Northern Alta, BP: before present (more precisely before AD 1950), PAN: Proto-Austronesian, P-CCO: Proto-Central Cordilleran, PEF: Proto-Extra-Formosan, P-NLZN: Proto-Northern Luzon (=Proto-Cordilleran), P-SCO: Proto-Southern Cordilleran, P-SCCO: Proto-South-Central Cordilleran. The empty parentheses in tables 6 through 8 indicate that some phonetic material was probably present in this position, but its reconstruction is uncertain. And an asterisk preceding an italicized form indicates an unattested modern form. 
lowlanders. ${ }^{4}$ Furthermore, it is the specific reflex of $* \mathrm{R}$ in each of these languages which provides an important clue to the subgrouping relationship that each language has to other languages of the Philippines (Reid 1987).

There are several points of contention regarding the reconstruction given above. Zorc (1979:8) has reconstructed Proto-Philippines *qaGta? 'Negrito, black person', while Blust (1972) reconstructed PAN * qa(R)(CtT)a 'outsiders, alien people'. ${ }^{5}$ The questions concern a) whether the form is reconstructible with a medial consonant cluster or not, b) whether the form had a final glottal stop or not, ${ }^{6}$ and c) what the form actually meant.

Drawing on data from the Samal, ${ }^{7}$ Indonesian, and Oceanic languages which only show a single medial consonant and no final glottal stop, Blust concluded that a medial cluster could not be securely reconstructed, in that "languages that reflect this root with an intervocalic stop either do not permit consonant clustering at all or limit it to homorganic prenasalization" (Blust 1972:169). He claims that the final glottal stop was innovated in one of the Central Philippine languages and spread to its neighboring languages, giving such forms as Bikol agta? 'Negrito person', Cebuano agta? 'large supernatural black creature living in caves, trees and empty houses who likes to play tricks on people, to kidnap them, and has a cigar in his mouth, also sometimes applied to Negritos' (Wolff 1972), which reflect a final glottal stop, the usual reflex of PAN *q in Philippine languages. But note Tagalog agta 'Negrito' and Western Bukidnon Manobo agta 'a kind of chicken which is black; in folk tales, black people', neither of which has a final glottal stop. ${ }^{8}$ Northern Philippine languages provide no evidence since final glottal stop was regularly lost in those languages.

Reflexes of *qaRta(q), with the medial cluster, occur throughout Philippine languages, including both central and southern Philippines. The names Ita or Aeta are also used for some groups that have a $y$ reflex of * $\mathrm{R}$, and are probably developments of the term Ayta, a form that has been borrowed widely into other Philippine languages as well, such as Maranao aita? 'Negrito - mountain people with kinky hair and small stature' (McKaughan \& Macaraya 1967:7).

4 The Central Cagayan Agta refer to the Ilocanos as ugsin, the Casiguran Agta call them ugdin, while the Alta refer to non-Negritos as uldin. These terms appear to have developed from a Proto-Northern Luzon form *?uytin, which is also reflected in Ibanag uzzin, Atta ujjoijin 'red', giving an interesting insight into the possible reason for the name. Perhaps the in-migrating Austronesians were originally perceived as having red skin. The Arta call a non-Negrito person agani, which appears to be cognate with Ilokano agáni 'to harvest rice; one who harvests rice' (Reid 1971, 1994b).

5 Given Blust's more recent views on higher-level subgroups in Austronesian, and the lack of any Formosan cognate, the reconstruction should only be made as far back as his Proto-Malayo-Polynesian. Zorc's *G and Blust's *R both represent what was probably a velar fricative $/ \mathrm{\gamma} /$ (or perhaps uvular $/ \mathrm{s} /$ ) in the parent language, and since PAN ${ }^{*} \mathrm{C}$, ${ }^{*} \mathrm{t}$, and ${ }^{*} \mathrm{~T}$ are all reflected as $* t$ outside of Taiwan, there is no need to reconstruct a set of ambiguous phonemes as the second consonant of the cluster. In addition, Blust's two uses of parentheses in *qa(R)(CtT)a serve differing functions. The first parentheses imply that the data are insufficient to definitively reconstruct $* \mathrm{R}$ in that position, while the second set implies that the data are insufficient to be definitive about which of the three- ${ }^{*} \mathrm{C}$, $* \mathrm{t}$, or $* \mathrm{~T}$ - was the protosound in that position.

6 Although a few Philippine languages (Tboli, Agutaynen, and Kalamianen) show /k/ as a reflex of PEF $* \mathrm{q}$, the usual reflex in Philippine languages is glottal stop.

7 Samal is a Sama-Bajaw language spoken in the southern Philippines, but is not a Philippine language. The Sama-Bajaw languages are now classified as belonging to the Barito family of languages of southeast Kalimantan (Blust 2005:45).

8 For Maranao, McKaughan \& Macaraya also give ate? 'chicken with black feather and flesh, person who is dark brown to black' (1967:31); and agta? 'witch, demon—black'(1967:5). 
The names of other groups who identify themselves as Negrito, such as the Ati groups of northern and southern Panay, and the Ata groups of Negros, may be irregular reflexes of the same name, but are more likely to be exonyms adopted by the groups to refer to themselves, based on one of the linguistic features that the group uses which differentiates them from their farming neighbors. Thus the language of Samar-Leyte is called Waray, since waray is their term for the negative existential 'there is none', which in most of the other Bisayan languages is walay. The forms * ti and *ta are demonstrative bases reconstructible to very early protolanguages in the Philippines. The former generally has the meaning 'that (remote)'. Zorc (1974:589) notes, however, that in a few languages, specifically the Central Luzon group and Iraya of Northern Mindoro, $t i$ is the base for demonstratives denoting nearness. Likewise the use of $t a$ as a base denoting remoteness is found only in Kapampangan (a Central Luzon language) and in some of the Northern Mindoro languages. Neighboring languages in Northern Mindoro show completely opposite uses of these bases, thus for 'that (yonder)', Tadyawan has ata, and Alangan has ati.

Inati, the language of the Ati of Panay, shows the shifted meanings of both demonstratives which occur in the Central Luzon and Northern Mindoro languages. Namely, $t i$ occurs in demonstratives indicating 'this (either near speaker, or near speaker and addressee)', whereas te (a reflex of *ta) occurs in the demonstrative indicating 'that (remote)' (Pennoyer 1986-87:15-16). It is possible then that at least the Ati name is not etymologically related to $\mathrm{PEF} * \mathrm{qaRta}(\mathrm{q})$ at all, but reflects the particular developments that occurred in the demonstrative system of this language, which distinguishes it from its neighbors. ${ }^{9}$

There is one other group who call themselves Ata. They are a medium-sized group, 26,653 in 2000 according to the Ethnologue (Gordon 2005), who live in central Mindanao. However, they do not identify themselves as Negrito but as Manobo and are not primarily hunter-gatherers. Given the relatively widespread distribution of Negrito groups in Luzon and parts of the Visayas, and the fact that there is only one extant Negrito group speaking a language distinct from its neighbors in Mindanao (the Mamanwa), it is probable that other Negrito groups are now completely assimilated into Manobo, and perhaps other language families in Mindanao, accounting not just for the remnant Ata name, but for the relatively darker skin and curly hair of many Manobo people, especially the Tigwa and Matigsalug groups who are linguistically fairly-closely related to the Ata Manobo. This is supported by the fact that the term agta? is found in Manobo folktales, to refer to dark-skinned people and by extension even for a chicken with black feathers (Elkins 1968), and is used in Sarangani Manobo as a verb meaning 'to chase, to pursue, to hunt small game' (DuBois 1974). In Tausug, one of the Central Philippine languages, but spoken in the Sulu archipelago in the south of the Philippines, the term also occurs in legends to refer to 'a short, black antagonistic, ill-looking woman, evil-minded but wise' (Hassan et al. 1994). Both terms - Ata 'Manobos of Libuganon, Kapugi, Langilan, Kapalong; Ata of Davao' and agta? 'a person with black skin, a Negrito; used in folklore'-are found in Dibabawon Manobo (Forster \& Barnard 1976:9, 23).

Blust (1972) attempts to justify his reconstruction of the meaning of the form as 'outsider, alien people' instead of the meaning 'slave' that had earlier been proposed by Dempwolff (1938), both of which meanings appear in various languages. Some languages have the meaning 'man' but this gloss is rejected by Blust for the reconstructed form,

9 Jason Lobel (personal communication, 12 July 2006) suggests the possibility that although the languages are very dissimilar, the language names Inati and Inata are related, in that Pennoyer notes that the Ati of Northwest Panay call their language Inete (where $e[\varepsilon]$ is a reflex of both *a and *a). Pennoyer (1986-87:7) also notes that he recorded three variations of the name of the group: Ati, Ete, and Ata. 
because of the conflict with the much more widely occurring form, reconstructed as PAN *Cau. He considers that Negrito groups that now use reflexes of his Proto-MalayoPolynesian * qaRta(q) have adopted the term applied to them by non-Negrito groups. I find this scenario highly unlikely, in that Negrito groups, until probably relatively recently, have carefully maintained their own identity, and still reject the wide range of derogatory names by which outsiders call them. A far more likely scenario is that those groups in which the gloss of the term is 'man, human being' have assimilated Negritos into their group and have replaced a reflex of PAN ${ }^{*} \mathrm{Cau}$ with the term that the Negritos used for themselves.

\section{TIME DEPTH OF FIRST INTERACTION BETWEEN NEGRITO AND NON-NEGRITO GROUPS}

The Negrito groups are considered to be the earliest inhabitants of the Philippines. We know this from an examination of the archaeological evidence which clearly places the earliest movement of Neolithic peoples from Taiwan around 4500 to 4000 years ago. ${ }^{10}$ Pottery from Torongan and Sunget in the Batanes Islands between Taiwan and Luzon has been dated to between 3600 and 3000 BP, and Taiwan jade dated to c. 3500 BP has been recovered from an archaeological site at Nagsabaran in the Cagayan Valley of northern Luzon (Bellwood et al. 2003, Bellwood \& Dizon 2005). We assume that prior to the first movement of an Austronesian-speaking group from Taiwan, the Philippines was probably occupied by maybe several hundred or more separate groups, with widely disparate languages, not unlike the distribution patterns of peoples in New Guinea. The earliest human record of occupation (in the Tabon caves) has been dated at more than 40,000 years ago, and genetic evidence (the occurrence of unique alleles) suggests that the Negrito groups in Mindanao may have been separated from those in Luzon for twenty to thirty thousand years (Omoto 1981).

Prior to the arrival of Austronesian-speaking people into the northern Philippines from Taiwan, it is probable that the Negrito groups occupied coastal areas, as they still do in northeastern Luzon, and also broad river valleys, such as that of the Cagayan River, subsisting off the readily available shell fish, the remains of which form extensive shell middens along the Cagayan River, and exploiting the animal and vegetable products widely available in the largely undisturbed grasslands and forests that filled the valleys.

Blust (2005) speculates that from the initial Austronesian settlement of the Philippines (his Proto-Malayo-Polynesian) for perhaps a thousand years of agricultural expansion and language differentiation, the pre-Neolithic Negrito populations remained in their "exclusive preserve" (2005:54), the mountainous interior regions of the Philippines, apparently having no contact at all with Austronesians. He speculates that they were also probably hardly affected at all during his "First Extinction" (2005:39-41), a period during which he claims the expansion of one particular Austronesian-speaking group, in a competition between agricultural groups for the same territory, eliminated all of the diversity that had developed in the previous millennium, and became the parent (his Proto-Philippines) of all of the languages currently spoken in the Philippines and parts of Northern Sulawesi. It was only subsequent to these events, he believes, that meaningful contact was established between the Negrito hunter-gatherers in their "remote mountain

10 Peter Bellwood states, "We have a new site, Reranum Cave, right at the northern end of Itbayat. It has red slipped ware and some sherds of fine-cord marked pottery, a classic type in Taiwan around 4500-4000 BP. We also have dates of 4000 BP from Torongan Cave also on Itbayat. As a matter of interest, we also know the site of Anaro on Itbayat was involved in manufacturing lingling- $O$ [earrings] of Taiwan jade around 2000-1500 years ago" (personal communication, 7 May 2006). 
areas" (2005:41) and the Austronesian-speaking farming populations that resulted in the loss of the Negritos' inherited languages and their adoption of Austronesian languages.

It is inconceivable to me that the Negritos would have chosen to live in such remote mountain areas, rather than in the valleys and seashores where food supplies would have been far more abundant and readily obtainable. Bellwood refers to them as "traditionally forest and coastline hunters and gatherers" (1985:72). There is considerable archaeological evidence to support this claim, notably the extensive shell middens near Lal-lo and other sites along the lower Cagayan River in northern Luzon. The lower levels of these midden sites date to $5000 \mathrm{BP}$, at least a thousand years prior to the Austronesians' arrival in the area, while the upper levels date to 4000 BP (Paz 1999:154). There are also pre-Neolithic remains in cave-sites in the area. Furthermore, the Dumagat (or 'sea-going') Negritos along the eastern coast of northern Luzon, have long been associated with the ocean and river valleys that drain the eastern slopes of the Sierra Madre, the mountain chain that separates the Cagayan Valley from the Pacific coast (see section 5 below for a fuller discussion of these groups), while the name of the Mamanwa Negrito group in Mindanao means 'people of the forest' (Miller \& Miller 1976:17). Blust's isolationist view runs counter to recent scholarship which demonstrates that inter-ethnic trade has been the pattern of contact between hunter-gatherers and farmers since Holocene times and that claims of isolation have usually been shown to be mythological (Headland \& Reid 1991).

I have claimed instead that contact with Negritos must have occurred soon after the first arrival of the Austronesian-speaking migrants, and that they developed a pattern of interaction with Negritos which resulted in the loss of the Negritos' original languages in favor of the language of the group that they were interacting with. Their adaptation to the remote mountain areas must have gradually come as the expanding agriculturalists took over the Negritos' traditional hunting and gathering sites in the lower altitudes for farming, and conflict between the groups motivated them to move to more remote areas to avoid the farmers.

We know that the first Austronesian-speaking migrants into the Philippines were a technologically advanced group compared to the Negritos. They were not only weavers and pot-makers; we know also that they were agriculturalists with a long history in Taiwan of rice and millet agriculture (Blust 1995, 1976). That they brought rice with them is clear not only from the linguistic evidence of reconstructed forms for Proto-Austronesian such as for the rice plant, for harvested and cooked rice, rice husk, and mortar and pestle (reflexes of which are found throughout the Philippines), but also from the very early date available for a rice husk ( $3400 \mathrm{BP} \pm 125)$, recovered in Andarayan in the northern Cagayan River Valley (Snow et al. 1986). That the Negritos must have survived on a diet of relatively insufficient carbohydrates (perhaps accounting for their short stature) has been discussed in various places (e.g., Headland \& Reid 1989, 1991), and probably relatively soon after the Austronesian-speaking migrants arrived, developed a taste for rice, satisfying as it did some of their nutritional needs. Early migrants would not have been numerous, and it would have been to the advantage of the in-migrating Austronesians to develop a good relationship with the Negrito bands they certainly must have encountered, or they would have been slaughtered.

A pattern of interaction between the two groups probably developed in the very early stages of contact, whereby the Negritos assisted the in-migrants with felling of forest trees and preparation of swiddens for dry rice cultivation, and ultimately of pondfield development for wet rice, a pattern that has persisted into historical times. 


\section{PATTERNS OF INTERACTION WITH FARMING GROUPS}

Although Negrito populations in the Philippines all now speak Austronesian languages which are relatable to the languages of the farming groups with whom they interact, the degree of that relationship varies widely. Reid (1987) explores the question of what this variation implies for the prehistoric interaction between the groups and presents a number of possible scenarios to account for the different types of relationship between them. Four possible scenarios are discussed, each of which will be outlined in the following sections. ${ }^{11}$

\subsection{The relatively-recent hypothesis}

It is conceivable that the language shift to an Austronesian language took place relatively recently in cases where total assimilation has taken place and no record is left of the prior language, or in cases such as the Atta dialect of Pamplona which is said to share 91 percent of its basic vocabulary with its closest neighbor, Ibanag. But given the same facts, it is possible that these same groups could have lost their original languages thousands of years ago, and by maintaining continual intimate contact with their neighbors shared in all the changes in the dominant language community, a hypothesis which is discussed next.

\subsection{The relatively-remote-with-continual-contact hypothesis}

Evidence for continual contact over an extended period is found when one considers the large number of Spanish loanwords in Atta. Certainly the Negrito groups didn't have the kind of contact with Spanish that would have brought about such large-scale borrowing, whereas the Ibanag did have, resulting in a massive influx of Spanish loanwords into their language. The Atta, because of their continual and intimate contact with Ibanag, at least since the early Spanish period in the Philippines, have borrowed many of these forms into their own language.

\subsection{The relatively-remote-with-cyclic-contact hypothesis}

This hypothesis proposes that a group of Negritos could have learned their first Austronesian language at a remote period, subsequently withdrawn from their neighbors, resulting in normal language split, and then at a later date re-established intimate contact with them, resulting in extensive borrowing from them or even replacement of their Austronesian language. Linguistically, it would be difficult to distinguish between this situation and the preceding one, where contact had not been broken for an extended period. It is probable, however, that some of the Negrito languages of the east coast of northern Luzon fit this scenario.

Some of these appear to be quite closely related to one another, others of which are considerably different. Magaña (2003:242-243) claims that "the total population of Agta [...], as of the year 2000 is 1,828 [... in] ninety-nine villages grouped as bands in twenty-seven barangay [...] in the five municipalities [Palanan, Divilican, Maconacon, San Mariano, and Dinapigue] of the NSMNP [Northern Sierra Madre Natural Park]." This number does not include the Dupaningan Agta found in numerous bands along the coasts and valleys to the north, in eastern Cagayan Province as far north as Palaui Island, just off the northern shore of Luzon.

The most closely related set of languages are the Dupaningan Agta in eastern Cagayan Province, the Palanan Dumagat Agta in Isabela Province and the Casiguran Dumagat Agta in Aurora and Quirino Provinces, which share from about 70 percent of

11 Much of the information in these sections previously appeared in Reid (1987). 
basic vocabulary in the case of Dupaningan Agta and Casiguran Dumagat, to 87 percent in the case of Palanan Dumagat and Casiguran Dumagat (Headland 1975, based on the 372 wordlist of Reid 1971).

Each of these languages has a $g$ reflex of $* \mathrm{R}$, a feature which is shared with the Northern Cordilleran languages such as Ibanag, Itawis and Yogad that are spoken in the Cagayan Valley to the west of the Sierra Madre range. Casiguran Dumagat is the bestdescribed of these languages, and has a number of features which make it look very conservative. It has been grouped as a Northern Cordilleran language (Tharp 1974:101), primarily on the basis of its $g$ reflex of $* \mathrm{R}$, yet it does not share in a considerable number of other phonological innovations which characterize other members of that group, such as *ə to $a$, gemination of a single root-medial consonant following its reflex of $*_{\partial}, *_{s}$ to $t$, and *t to $s$ following $*_{i}$. McFarland's (1980:66) subgrouping agrees with Tharp's in placing the Dumagat languages in a group coordinate with other Northern Cordilleran languages.

Apart from a large influx since the 1960s of immigrant groups of farmers speaking languages of the Cagayan Valley and the Cordillera Central, there are two non-Negrito languages spoken on the east coast of northern Luzon: Kasiguranin and Paranan. Casiguran Dumagat Agta and Palanan Dumagat Agta both share a considerable number of lexical and grammatical features with these languages (respectively), a fact which I investigate more fully in section 5 below.

The facts seem to support the hypothesis of this section, that the Negrito groups learned the language of their non-Negrito neighbors at a fairly remote period, certainly long enough ago for the present differentiation among the Negrito groups to have taken place, and also long enough ago for the changes to have taken place that now distinguish these languages from the languages of the farmers in the area.

Because of the paucity of information available for Palanan Dumagat and Dupaningan Agta, examples are given here only for Casiguran Dumagat. These changes are of two types, those that are probably innovations in the Negrito languages not shared by their neighboring farmers, and those that are probably innovations in the language of their neighbors that are not shared by the Negrito languages. Of the first type, Casiguran Dumagat has changed the old $\mathrm{PEF} *$ di locative preposition, which is still found in Paranan, from marking only singular nouns to marking only plural nouns. (The forms to and ta are now used in Casiguran Dumagat to mark singular locative common nouns.) Casiguran Dumagat has extended the function of $d i$ to include also nominative and genitive (Headland \& Headland 1974). ${ }^{12}$

Of the second type, Casiguran Dumagat retains unreduced forms of the completed aspect of the reconstructed Proto-Extra-Formosan verbal prefixes (table 1). In Proto-Extra-Formosan, verbs were marked as completed aspect, or past tense, by infixing $*<$ in $>$ following the first consonant $(* \mathrm{~m}-)$, of the verbal prefixes. Paranan, and all other

Table 1. The development of verbal prefixes

\begin{tabular}{|l|l|l|}
\hline PEF & Casiguran Dumagat & Paranan \\
\hline$*_{\mathrm{m}<\mathrm{in}>\mathrm{aR}-}$ & minag- & nag- \\
\hline${ }^{*} \mathrm{~m}<\mathrm{in}>\mathrm{aN}-$ & minaN- & naN- \\
\hline${ }^{*} \mathrm{~m}<\mathrm{in}>\mathrm{a}-$ & mina- & na- \\
\hline
\end{tabular}

12 Headland \& Headland use the terms oblique, topic, and attributive (for my locative, nominative, and genitive, respectively). 
Northern Cordilleran languages (as well as Ilokano, and the non-Negrito Central and Southern Cordilleran languages), have subsequently reduced these infixed forms by deleting the first two segments, thus setting up an $m$ - $/ n$ - nonpast/past paradigm.

The evidence, then, fairly clearly points to a very early contact with Austronesian speakers in the area which was probably near the place where Austronesians first entered the Philippines (assuming that they came south from Taiwan). This contact has apparently been maintained over thousands of years in a cyclic fashion, allowing for normal language differentiation as well as continuing diffusion of features, primarily lexical items from Paranan, Kasiguranin, and other linguistic groups, such as Ilokano and Tagalog, with which they have from time to time associated, while maintaining features of the early Austronesian language that they first acquired.

\subsection{The relatively-remote-with-cyclic-contact-with-a-different-language hypothesis}

A much more interesting hypothesis, because it is potentially more revealing of the prehistoric situation, is that a Negrito group learned its first Austronesian language at some remote date, and then lost contact with its neighbors, either because they themselves moved, or-as appears to be more likely - their non-Negrito neighbors were driven off by other expanding non-Negrito populations. Subsequently the Negritos established contact with another language group, such as the in-migrating group, being affected to a greater or lesser degree by the nature of this contact.

One would expect in a situation such as this, that some evidence would remain of the original language that had been learned. For example, the sound shifts that characterized the original Austronesian language would be found in at least the basic vocabulary of this Negrito language, and there would be an identifiable body of vocabulary which would appear to be borrowed from the language or languages with which later contact had been maintained. One might also expect to find features of morphology and syntax that agree more closely with those of the language family with which it was first associated than with the language with which it was subsequently associated. In the following sections I will discuss two languages, the nature of which can be explained by a hypothesis of this sort.

\subsubsection{Sinauna Tagalog}

Literally 'ancient Tagalog', Sinauna Tagalog is (or was) spoken in and around Tanay, Rizal Province, in the middle of a Tagalog-speaking area (Santos 1975). A close dialect of the language, spoken just across the Sierra Madre range around the town of Infanta, Quezon Province, has been called Infanta Dumagat. The Sinauna Tagalog identify themselves as Tagalogs. The younger people all speak Tanay Tagalog. The language of the older people is not Tagalog, although it is heavily larded with Tagalog words. However, their language retains a number of features that clearly indicate that their language is genetically part of the Central Luzon group (which includes the non-Negrito Sambal languages of Botolan and Tina, as well as Kapampangan), much farther to the north, and is not most closely related to Tagalog at all. See Himes (this volume) for more on the Central Luzon group.

These features include a number of basic lexical items having a $y$ reflex of Proto-Austronesian *R (table 2). This is the regular reflex in the Central Luzon languages, whereas the regular Tagalog reflex is $g$. 
Table 2. Examples of the $y$ reflex of PAN * $R$ in Sinauna

\begin{tabular}{|l|l|l|}
\hline PEF & Sinauna Tagalog & Gloss \\
\hline *?ikuR & 2ikuy & tail \\
\hline *?uRat & iuyat & vein \\
\hline *baiəRu & baiyu & new \\
\hline *bəR?at & baiyat & heavy \\
\hline *buRəw & buyaw & drive away \\
\hline *hiRup & 2iyup & sip \\
\hline *Ruan & payway & gap \\
\hline
\end{tabular}

Note: The form buyaw is from the Infanta Dumagat dialect of Sinauna.

Table 3 presents forms which illustrate the regular Sinauna reflex of PAN * . As in the other Central Luzon languages, it is a, whereas in Tagalog, the regular reflex is $i$.

Table 3. Examples of the a reflex of PAN *o in Sinauna

\begin{tabular}{|l|l|l|}
\hline PEF & Sinauna Tagalog & Gloss \\
\hline *?ənəm & Pa?nam & six \\
\hline *?ətut & Pa?tut & fart \\
\hline *?utək & Putak & brain \\
\hline *bəR?at & ba?yat & heavy \\
\hline *buək & buak & hair \\
\hline *yipən & gipan & tooth \\
\hline
\end{tabular}

A cursory comparison of some of the verbal affixation in Sinauna, Kapampangan, and Tagalog (table 4) shows that the Sinauna forms agree more closely with Kapampangan than with Tagalog. Both Sinauna and Kapampangan use a change in vowel ( $a$ to $i$ ) to distinguish past tense from present. In addition, Sinauna and Kapampangan retain $m$-initial forms for all tenses. Although this is a retention from the protolanguage and therefore of little value for establishing a subgrouping relationship, it is apparent that Sinauna does not participate in the innovations that resulted in the $n$-initial forms found in Tagalog.

It is significant that the full, unreduced forms of the completed aspect of ProtoExtra-Formosan verbs (table 1) were apparently also continued into Proto-Central Luzon. In some of the Central Luzon languages the pattern of reduction was generally different from that in the languages in the north of Luzon, the third and fourth segments being deleted, resulting in an $\langle a\rangle \mid<i>$ nonpast/past paradigm. Botolan Sambal (Antworth 1979), on the other hand, has reduced its perfective affixes in the same way, as did Paranan, as well as most of the other languages of Luzon. The $\langle a\rangle \mid<i>$ nonpast/past paradigm also occurs in Mamanwa, a Negrito 
Table 4. Comparison of Sinauna verb affixation

\begin{tabular}{|l|l|l|l|}
\hline Tense/Aspect & Sinauna & Kapampangan & Tagalog \\
\hline Present & mag- & mag- & mag- \\
\hline Progressive & mina:g- & marg- & nagCV:- \\
\hline Past & mig- & mig-, meg- & nag- \\
\hline Future & magCV- & mag- & magCV:- \\
\hline
\end{tabular}

Note: $C V$ - stands for consonant-vowel reduplication, with $:$ representing vowel length.

language in northeast Mindanao, but not as far as I have been able to discover in other East Mindanao languages. In Maranao, only the medial $n$ was deleted, setting up an $\langle a\rangle|<i a\rangle$ nonpast/past paradigm (Reid 1987:50).

Sinauna, however, alone among the Central Luzon languages, still maintains the unreduced form in part of its verbal paradigm, as can be seen in table 4, distinguishing it again from the other members of that family, and giving evidence that the language was learned from the Sinaunas' non-Negrito neighbors at a very early period in the development of the Central Luzon language family.

If we now look at free nominative pronouns for Sinauna, Kapampangan, Botolan Sambal, and Tagalog (table 5), we see that Sinauna shares at least one innovation with the Central Luzon family that is not shared by Tagalog, that is, loss of the final $w$ from the second-person singular (2s) form. Similarly, Sinauna does not share in the innovation reflected in the Tagalog first-person inclusive plural $(1,2 \mathrm{P})$ form, which changed PEF $*=$ tamu into $=$ ta:yo.

It is of interest also to note that Sinauna maintains features that were probably present in Proto-Central Luzon, but have been subsequently lost in all other Central Luzon languages. Inspection of these forms shows Kapampangan suffixing its pronominal bases to a personal noun specifier $2 i$, and Botolan Sambal instead suffixing them to $h i$ from *si. Sinauna suffixes its pronominal bases to either si?i or si?, apparently reflecting an earlier system in which a sequence of personal noun specifiers (*si and *2i) were the forms to which pronominal bases became encliticized and later suffixed.

An alternate hypothesis, that Kapampangan actually reflects the original form of the personal noun specifier and that it was replaced by *si after the dispersal of the family, is also possible. Under this hypothesis, the evidence would suggest that Sinauna is more closely related to Botolan Sambal than to Kapampangan.

It is clear from the above evidence that Sinauna is indeed a Central Luzon language. Its geographic location, in the middle of a Tagalog speaking area, could be the result of either a northward in-migration of Tagalog speakers, or a southward shift in the hunting range of the Negritos. It is probable that in this case it is the Negritos who have retained their traditional foraging areas and it is their earlier Central Luzon speaking neighbors who migrated north under the pressure of in-migrating Tagalogs from Marinduque and Mindoro in the Central Philippines (Zorc 1993; Gonzalez 2005:94). 
Table 5. Central Luzon and Tagalog nominative pronouns

\begin{tabular}{|c|c|c|c|c|}
\hline & Sinauna & Kapampangan & Botolan Sambal & Tagalog \\
\hline $1 \mathrm{~S}$ & saku & Paku & hiku & Pako \\
\hline $2 \mathrm{~S}$ & si?ika & Pika & hika & Pikaw \\
\hline $1,2 \mathrm{~S}$ & si?itadaw & Pikata & hita & kata \\
\hline $3 \mathrm{~S}$ & sirya & Piya & hiya & siya \\
\hline $1 \mathrm{P}$ & si?kami & Pikami & hikayi & kami \\
\hline $2 \mathrm{P}$ & si?kamu & Pikayu & hikawu & kayo \\
\hline $1,2 \mathrm{P}$ & si?tamu & Pitamu & hitamu & ta:yo \\
\hline $3 \mathrm{P}$ & sira & Pila & hila & sila \\
\hline
\end{tabular}

Evidence that the Tagalogs are the latecomers to this area is considerable, and is generally accepted by linguists. Zorc writes, "When the Tagalogs first migrated to Southern Luzon, they came in contact with various Northern Philippine languages such as Kapampangan, Sambal, and (later?) Pangasinan. Through centuries of contact, trade, and intermarriage, these languages were displaced by Tagalog or moved north" (1979:vii). The geographical extent of this early language with which the Ayta Negritos can be associated has been suggested by Zorc (1974). He has presented a number of features in the languages of Mindoro, including * $\mathrm{R}$ to $y$, that appear to be probable shared innovations with the Central Luzon group and possibly with Bashiic in the far north, indicating that at least the northern languages of Mindoro are probably more closely related genetically to these northern groups than they are to the other languages of the Central Philippines.

\subsubsection{The Alta languages}

There are two Alta languages spoken by Negritos over a fairly wide area of the Sierra Madre from eastern Nueva Ecija to the boundary of Aurora and Nueva Vizcaya Provinces north of Maria Aurora. The northern and southern Alta languages are very different from one another, and are not mutually intelligible. The only published materials for Northern Alta are Vanoverbergh (1937), who refers to the language as Baler Negrito, and Reid (1991); the latter also provides the only published data on Southern Alta. For the purposes of this paper, I will restrict my discussion of these Negrito languages to Northern Alta.

Although the Northern Alta live in the same general area (the Baler River Valley and environs) as the southern Ilongot, who speak a language of the Southern Cordilleran family, their primary contacts, especially in the Dingalan area and in Nueva Ecija are with speakers of Tagalog. Consequently, most Northern Alta are bilingual in this language. This contact has continued for long enough that the language shows a considerable number of Tagalog borrowings. There appears to have been considerable contact also between Northern Alta and other Negrito groups, especially those speaking dialects of the Umiray Dumaget language (as in section 3.5.2) who are scattered down the eastern coast of Luzon.

The genetic relationship of the Alta languages, however, is probably with the South-Central Cordilleran languages. These include Kalinga, Bontok, and Ifugao (Central Cordilleran) and Pangasinan, Ibaloi, and Ilongot (Southern Cordilleran). The Alta languages are the only extant Negrito languages to be related to this group. 
Their genetic relationship is indicated by their $l$ reflex of $* \mathrm{R}$, the reflex also found in the South-Central Cordilleran languages (table 6). All of these languages, including Alta, also share an innovation in the system of verbal prefixes. The reflex of the Proto-Philippine intransitive verb prefix *maR- in these languages should be *mal-. Instead, all show a reflex of *man-.

Table 6. Examples of the $l$ reflex of PAN *R in Northern Alta

\begin{tabular}{|l|l|l|}
\hline PEF & ALTN & Gloss \\
\hline$*$ qaRta(q) & Palta & man \\
\hline$*($ duR & Padul & thunder \\
\hline *baqəRu & bulu & new \\
\hline *bahaR & bal & loincloth \\
\hline$*$ diRus & dilus & bathe \\
\hline$*$ huRas & Pulas & wash \\
\hline$*$ kaRat & Palat & bite \\
\hline *niuR & niyul & coconut \\
\hline$*$ saNdiR & saygil & lean \\
\hline$*$ taRaqinəp & tale:nip & dream \\
\hline$*$ wiRi & Pawilih & left hand \\
\hline
\end{tabular}

There are several very conservative features of Northern Alta which suggest that these Negritos switched to speaking an Austronesian language at a quite remote time. These features are as follows. Two of the lexical items cited in table 6 have been replaced in all of the other Central and Southern Cordilleran languages. These are the words for 'coconut' and 'dream'. Only in Northern Alta are these terms preserved with an $l$ reflex of *R, the way they must have been pronounced in Proto-South-Central Cordilleran. Northern Alta, like other Negrito languages discussed above, also maintains unreduced forms of the completed aspect of verbal prefixes. All other Central and Southern Cordilleran languages have reduced them to $n$-initial forms.

The other conservative aspect of Alta is its pronominal system. The pronouns of Northern Alta do not reflect innovations that have occurred in all of the other languages of this subgroup. Table 7 compares the free nominative pronouns of Northern Alta with the forms reconstructed for Proto-Southern Cordilleran, Proto-Central Cordilleran, and ProtoNorthern Luzon (also called Proto-Cordilleran), the parent of all the Cordilleran languages-including Northern Cordilleran, not otherwise mentioned here (Reid 1974, 1979; Tharp 1974). For instance, Northern Alta does not share in the loss of final ${ }^{*}$-w from the second-person singular (2S) form, as have all other Central and Southern Cordilleran languages. Neither does Northern Alta share in the loss of the penultimate syllable *mu from the second-person plural (2P) form, as have all other Central and Southern Cordilleran languages. Northern Alta instead lost the final three segments of the original pronoun. Furthermore, Northern Alta does not share in either of the innovations that occurred in the pronominal formatives marking first-person inclusive plural (1,2P). In Southern Cordilleran 
Table 7. Nominative pronouns in Northern Alta and other Cordilleran languages

\begin{tabular}{|c|c|c|c|c|c|}
\hline & ALTN & P-SCO & P-CCO & P-SCCO & P-NLZN \\
\hline $1 \mathrm{~S}$ & siiวn & siyak & sakən & siyakən & siyakən \\
\hline $2 \mathrm{~S}$ & sipaw & si?ika & sik?a & si?ika & si?ikaw \\
\hline $1,2 \mathrm{~S}$ & si?e:ta & si?ikita & da?ita & siPikita & si?ikita \\
\hline $3 \mathrm{~S}$ & siya & siya & siya & siya & siya \\
\hline $1 \mathrm{P}$ & si?ami & siPikami & dakami & si?ikami & siPikami \\
\hline $2 \mathrm{P}$ & si?am & si?ikayu & dakayu & si?ikayu & si?ikamuyu \\
\hline $1,2 \mathrm{P}$ & si?e:tam & siPikitayu & dataku & siPikita() & si?ikitam \\
\hline $3 \mathrm{P}$ & siddo & siPida & da?ida & si?ida & siPida \\
\hline
\end{tabular}

the original form became $=t a y u$, in Central Cordilleran it became $=t a k u$. In Northern Alta the form is =tam, a reflex of the form reconstructed for Proto-Northern Luzon.

There is also an innovation that took place in the genitive pronoun set of Southern Cordilleran languages that is not shared by Northern Alta. In these languages the third-person singular (3S) genitive pronoun $*=$ na is replaced by $=t u$. Alta retains $=n a$, the form which is reconstructed for Proto-Northern Luzon. Northern Alta is also different from the South-Central Cordilleran languages, in that its locative personal pronouns are attached to the locative case-marking preposition $d i$, like the Dumagat languages already described, rather than with a reflex of *ka-ni. Ivatan (spoken in Batanes Province) is the only non-Negrito language in the north that has locative personal pronouns case-marked with $d i$.

It seems likely then that the Alta languages are the only languages to retain pronominal forms that were probably present in Proto-Meso-Cordilleran, the immediate parent of Proto-South-Central Cordilleran and Proto-Alta. A diagram showing the relationships among the Northern Luzon languages is listed in appendix C.

\subsection{The relatively-remote-with-little-subsequent-intimate-contact hypothesis}

The most interesting hypothesis would be that a Negrito group switched languages at a remote period, as a result of intimate contact with one of the early Austronesian protolanguages in the Philippines, then went its own way, without subsequent intimate contact with that language or any subsequent daughter languages of the protolanguage, perhaps until the historical period. Such groups would appear to be isolates, difficult to subgroup with other Philippine languages, and would potentially have great value for determining which features were present in the protolanguage. Such groups would probably have led relatively isolated lives in peripheral geographic areas with low population density, and like languages in other relic areas, would have retained features of the parent language which may have been lost in the more innovative languages of its immediate relatives.

Although there are several Negrito groups which perhaps fall into this category in that their languages appear to be very different from the languages of their immediate neighbors, and it is difficult to unambiguously group them with any other subgroup, they nevertheless show considerable lexical influence from local non-Negrito groups. This is to be expected, since within the historical period, at least, each of these groups has maintained close ties with 
their non-Negrito neighbors. In the following sections, three such groups-the Arta, the Umiray Dumaget of Luzon, and the Inati of Panay-will be discussed.

\subsubsection{Arta}

The Arta are a very small group of Negritos living along the Addalem River in the proximity of Aglipay and Maddela, Quirino Province, in northeastern Luzon. As of 1987, only about a dozen remaining speakers of the language could be found. They are generally referred to by local non-Negritos as Dumagats and assumed to be speakers of the same language as the Casiguran Dumagat Agta, some of whom also live in the area (Reid 1989).

An examination of the Arta reflexes of Blust's (1981) reconstructions of 200 basic lexical items indicates that Arta retains only 26.9 percent (51/189), almost 8 percent fewer than any other Philippine language for which similar scores have so far been calculated.

Arta, as its name implies, has the reflex $r$ for *R (table 8). The only other language in Luzon with an $r$ reflex for $* \mathrm{R}$ is Ilokano, suggesting the possibility that Arta may be most closely related genetically to Ilokano. However, Arta shares no other innovation with Ilokano and even though the language now exhibits a large number of borrowings from Ilokano, as it does also from other languages in the Cagayan Valley such as Yogad and Itawis, and Negrito languages of the east coast of Luzon, it appears not to subgroup with any of them. Arta has a fairly large percentage of unique lexical items, and some unique (for the area) phonological changes, including a zero reflex of both PAN ${ }^{*} \mathrm{q}$ and $* \mathrm{k}$, and a vowel-harmony rule not found elsewhere in the northern Philippines (Reid 1989).

Table 8. Examples of the $r$ reflex of PAN $* \mathrm{R}$ in Arta

\begin{tabular}{|l|l|l|}
\hline PEF & Arta & Gloss \\
\hline$*$ qaRta(q) & arta & man \\
\hline$*$ qəRəs & arəs & worm \\
\hline$*$ quRat & urat & vein \\
\hline$*()$ duR & adur & thunder \\
\hline$*$ baqəRu & buru & new \\
\hline$*$ dapuR & dupuran & hearth \\
\hline$*$ diRu & diru & soup \\
\hline$*$ huRas & uras & wash \\
\hline$*$ kaRat & uarat & bite \\
\hline$*$ taRay & taray & rib \\
\hline
\end{tabular}

Further evidence for the aberrant nature of this language is found in the numeral system. It has unique forms for the numerals 'one' and 'two', si:pay and tallip, respectively, and is the only Philippine language to use the term for 'person' as the numeral 'twenty', thus si:pay a arta 'twenty', tallip a arta 'forty', and lima arta 'one hundred' (literally, 'five people'). 
Arta, like other Negrito languages discussed above, also retains unreduced forms of the completed-aspect verbal affixes (table 1). As can be seen from appendix C, it is an isolate among the Northern Luzon (or Cordilleran) languages.

\subsubsection{Umiray Dumaget}

Umiray Dumaget is the Negrito language spoken in Umiray, Quezon Province, and in several other localities along the coast of Dingalan Bay and the Polillo Islands, reaching to Aurora, Nueva Ecija, Bulacan, and Rizal provinces as well. Although heavily influenced by Tagalog, it has a number of features that distinguish it from other languages in the area. It has a $g$ reflex of $*$ R, but does not appear to be closely related to any presently spoken non-Negrito language with the same reflex. It has generally been linked to the Agta languages along the coast to the north of it-Casiguran Dumagat, Paranan, and Palanan — with which it shares some features. However, Reid (1994b) suggests that Umiray Dumaget is not a Cordilleran language but rather that it is relatable to Bikol, a Central Philippine language. Himes (2002:275) writes:

While the evidence from phonological changes and the pronominal system does not compel us to favor one subgrouping over the other, the lexical data do show that DgtU [Umiray Dumaget] is most closely related to the Central Philippine languages. Culturally, we can infer that DgtU results from very early contact between the non-Austronesian-speaking Negrito population and speakers of that variety of Central Philippine that evolved into Tagalog, Bikol, and the Bisayan languages.

The Umiray Dumaget pronouns are similar to those found in Palanan and in the other Dumagat languages (table 9), but show that Umiray did not share in an innovation in the third plural (3P) form that characterizes Casiguran and Palanan, and it shows either a different pattern of reduction of the *sili personal noun specifier element in the parent language of this group (Umiray has only an $i$ ), or else it retains a reflex of an original *?i and never participated in the *si replacement which appears in Paranan and Casiguran. (Compare the pronominal features discussed above for Sinauna and the Central Luzon languages.)

Table 9. Nominative pronouns in Umiray Dumaget, Paranan, and Casiguran Dumagat

\begin{tabular}{|l|l|l|l|}
\hline & $\begin{array}{l}\text { Umiray } \\
\text { Dumaget }\end{array}$ & $\begin{array}{l}\text { Paranan } \\
\text { Dumagat }\end{array}$ & $\begin{array}{l}\text { Casiguran } \\
\text { Dumagat }\end{array}$ \\
\hline $1 \mathrm{~S}$ & iPako & sikan & sakan \\
\hline $2 \mathrm{~S}$ & iPaw & siko & siko \\
\hline $1,2 \mathrm{~S}$ & ikita & sikita & sikita \\
\hline 3S & iPeya & siya & siya \\
\hline $1 \mathrm{P}$ & ikami & sikami & sikame \\
\hline 2P & ikamo & sikam & sikam \\
\hline $1,2 \mathrm{P}$ & ikitam & sikitam & sikitam \\
\hline 3P & ida & hidi & side: \\
\hline
\end{tabular}


The case-marking systems of Umiray and the other Dumagat languages of the east coast of Luzon are unlike those of other Philippine languages (Reid 1978). The device for marking plurality in a common-noun phrase in Umiray is similar to that still found in Ivatan and in a few other languages such as Ibanag: the form of the third-person plural (3P) pronoun immediately following the pluralized noun. Paranan and most other Philippine languages, including Tagalog, place a (nonpronominal) plural marker between the case marker and the head noun. Addition of a plural form following the head noun was possibly a feature which was present in the parent language of the Philippines, but which has been lost in most of the extant languages. (See Reid \& Liao 2004:473-477.)

\subsubsection{Inati}

Inati of Panay (Pennoyer 1986-87), although surrounded by Bisayan languages (part of the Central Philippine subgroup), shows no evidence that these are the languages with which it is most closely related genetically. It appears to have a unique reflex of $* \mathrm{R}$, with about a dozen forms showing $d$ for $* \mathrm{R}$, whereas Bisayan languages have *R to $g$. It also appears likely that the inherited reflex of $*_{\partial}$ was $a$, like the Central Luzon languages, not $* u$ as in the Bisayan languages (e.g., PEF *liqəR > li?ad 'neck', *yakən > yakan 'mine', *bəkən > bakan 'negative') with *a $>e$ in some environments (e.g., PEF *Ramut $>$ yemot 'root', an interesting instance of $* \mathrm{R}$ becoming $y$ ). However, the reflex of the transitive suffix *-ən is $-i n$.

This language also shows a semantic reversal of the demonstratives $t i$ and ta that also occurred only in some of the Central Luzon languages (including Sinauna). In the Sogodnin dialect of Inati, $o$ appears as a nominative common-noun marker, a form which elsewhere occurs with this function only in Ivatan.

There can be no question that the ancestors of the Inati learned their language prior to the settlement of the Visayas by the people now speaking so-called Bisayan languages. Unfortunately the language has undergone so many changes that it is difficult to see which, if any, Philippine group it is genetically most closely related to.

An examination of the other Negrito languages of the Philippines, in light of the linguistic evidence discussed above-particularly the various Ayta languages of the Zambales mountain range, the Batak of Palawan, and the Mamanwa of northeast Mindanao - may shed further light on the kinds of relationships these peoples have had with their non-Negrito neighbors in prehistoric times.

\section{SUBSTRATUM QUESTIONS}

Although there are no clear cases of substratal elements in non-Negrito languages of the Philippines, one paper has been published which attempted to look for possible remnants of pre-Austronesian forms in the Negrito languages (Reid 1994a). The extremely long period of differentiation among the Negrito languages prior to the arrival of the Neolithic Austronesian-speaking population would suggest that there would have been little in common between the languages of remotely separated Negrito bands, such as those in Mindanao and northern Luzon. However, groups within the same area would undoubtedly have maintained periodic contact with each other, and the languages may well have been close enough to enable communication to take place. With this operating assumption, the available lexical material for Negrito groups in Luzon was searched for forms that were shared by Negrito groups, but for which no apparent cognate had been found in any Austronesian language.

A considerable number of unique terms were found some of which were fairly widely shared among contiguous groups, with some shared also with non-contiguous groups, but which did not have comparable forms in Austronesian languages. A fairly substantial 
number of them are part of the environment in which Negritos presumably lived and which tend to be culture-specific (e.g., abaca, rattan, sugarcane, coconut, betel leaf, rat, snake, buffalo, deer, dog, locust, crocodile, butterfly, termite, ant, mosquito), or secret language (e.g., vagina, penis). Such forms are suggestive of an original pidgin, in which basic vocabulary had been replaced with forms borrowed from the Austronesian language with which contact had been established, but so-called native cultural vocabulary was retained.

A further set of forms in the Negrito languages consists of look-alikes of forms in Austronesian languages, but with radical phonological and/or semantic change. Typically only the initial syllable of the Austronesian form was retained, or the Austronesian forms were systematically modified, as in Northern Alta in which terms with second syllables originally consisting of a voiced stop plus /a/ sequence have /d/ inserted before the second vowel, which is reflected as /a/, as in table 10 (Reid 1994a:52-56).

Table 10. Radical phonological change in Northern Alta

\begin{tabular}{|l|l|l|}
\hline P-NLZN & ALTN & Gloss \\
\hline *?abak & Pabdə? & body \\
\hline *?igat & Pigdət & eel \\
\hline *taba & tabdo & fat \\
\hline *laga?an & lagdən & light weight \\
\hline *?ugat & Pugdat & root \\
\hline *baba?i & dabdi & woman \\
\hline
\end{tabular}

Such terms would have hindered, rather than enhanced, communication with the Negritos' Austronesian neighbors, and suggest that after the loss of their original language and the creolization of the pidgin which first replaced it, such forms developed as a part of a secret language, and became linguistic markers of group identity.

\section{CREOLE QUESTIONS}

The data examined in the previous section suggest that the Negrito languages passed through a period of creolization, with subsequent decreolization as a result of thousands of years of intermittent interaction with Austronesian languages. There are, however, two Austronesian languages which provide evidence that they also may have begun as creoles. These are the languages Paranan and Kasiguranin mentioned above (in section 3.3). Relatively little data is available from either of these languages. For Kasiguranin, there is a short wordlist published in Vanoverbergh (1937). The pronouns, case markers and verb affixation of this language are almost identical to Tagalog. Lexically, however, Kasiguranin is very similar to its neighboring Negrito dialects-sharing, for example, 77 percent of its basic vocabulary with Casiguran Dumagat versus only 52 percent with Tagalog (Headland 1975). Although McFarland (1980) groups it with the Negrito languages, it seems to be the language of a group speaking an early Tagalog language that moved into the Casiguran Valley and was influenced by the Negritos in the area, a view first proposed by Vanoverbergh who comments, "Here, however, instead of losing the language they [the Negritos] had borrowed from their conquerors, they partly imposed it on their masters and brought into being a Casiguran dialect" (Vanoverbergh 1937:11). 
Paranan, on the other hand, although showing considerable influence from Tagalog, with 45 percent shared vocabulary (Headland 1975), clearly retains case markers and pronouns which are very conservative. Specifically, it appears to be the only language in Luzon that still retains a di locative preposition for common noun phrases, e.g., di bilay 'to the house', alongside proper noun locations, such as di Manila 'to Manila' (Finkbeiner 1983:6). Although $d i$ occurs in many languages with various other case-marking functions and occurs widely as the initial formative of locative adverbs and demonstratives, it is as a locative preposition that it is reconstructible for Proto-Extra-Formosan.

Although speakers of Paranan are now restricted to the geographical area around the town of Palanan, there is clear evidence that a wide area of northeastern Luzon was once occupied by people speaking a language that also had a di locative preposition. Nearly all of the old place names in this area have an initial $d i$ formant. Interestingly, these place names are mostly found within the present ranges of the Negrito groups being discussed in this section.

That the eastern coast of Luzon has been occupied by non-Negritos for thousands of years is supported by archaeological evidence (Peterson 1974). Excavations at Dimolit, a site in the Palanan Bay area, uncovered the postholes of house structures which are without doubt remains of an Austronesian settlement in the area, with pottery and grain-reaping knives. Peterson claims that the area was probably occupied between 2500 and 1500 BC. The present-day Paranans are perhaps the last linguistic survivors of that settlement.

Both Kasiguranin and Paranan, then, exhibit characteristics of either having once been creoles, or of having been relexified as a result of intimate contact with one or more of the Negrito languages in the area.

\section{CONCLUSION}

This paper has covered a number of fairly disparate themes with reference to the relationship between Philippine hunter-gatherers and their neighbors. Currently, probably none of the Philippine Negrito groups are pure hunter-gatherers. All have begun, with greater or less success, to introduce horticultural practices into their daily activities. This has primarily been the result of the massive loss of primary-forest cover through logging activities and the accompanying degradation of the environment and loss of game and other forest products which were the main source of livelihood of the hunter-gatherers.

Increasing intermarriage with non-Negrito groups, education, and incorporation into the social fabric of mainstream Philippine society is resulting in the rapid loss of the relatively few remaining Negrito languages in favor of the major languages of their neighbors: Ilokano, Tagalog, Bikol, and Cebuano.

Despite the general lack of in-depth information about the languages the Negritos have been speaking since soon after the arrival of Austronesian-speaking migrants into the Philippines from what is now Taiwan, sufficient detail is available to enable us to make at least the following claims.

1) The very conservative nature of the verbal morphology and the case-marking systems of a number of these languages implies that contact with the in-migrating farmers was established relatively soon after their first arrival in the country.

2) The contact was probably of an intimate sort - that is, Negritos and farmers living together in the same communities-with the children playing together and perhaps learning each other's languages.

3) Pidgins probably developed, with creoles forming within a generation or two. 
4) The Austronesian-speaking farmers were probably the dominant group on the basis of their technological know-how rather than their dominant numbers.

5) The Negritos were treated as serfs, working with the farmers to establish rice fields and being paid with part of the harvest. They probably also traded forest products for rice.

6) The relationship with farmers was intermittent. Conflict or other causes resulted in the separation of the groups, leading to the development of dialects and eventually separate languages.

7) The separation of the groups was not necessarily complete. Trading probably continued either with their former working partners, or with other Austronesian groups when the former group moved away or were replaced by farmers speaking another language.

8) Until relatively recently, within the historical period, many (if not most) Negrito groups were careful to maintain their own identity, distinguishing themselves from their neighbors by developing distinctive linguistic emblems, by calling themselves by a reflex of *qaRta(q) 'Negrito person', and having a distinct term for all non-Negrito people. 


\section{Appendix A. Negrito languages spoken in the Philippines}

\begin{tabular}{|c|c|}
\hline Language Name & Location \\
\hline Batak & Palawan \\
\hline Mamanwa & Northeastern Mindanao \\
\hline Ati & Panay, Negros \\
\hline Ata & Northern Negros \\
\hline Atta & Pamplona, western Cagayan Province, Luzon \\
\hline Atta & Faire-Rizal, western Cagayan Province, Luzon \\
\hline Atta & Pudto, Apayao Province, Luzon \\
\hline Abenlen Ayta & Tarlac Province, Luzon \\
\hline Mag-antsi Ayta & Zambales, Tarlac, and Pampanga provinces, Luzon \\
\hline Mag-indi Ayta & Zambales and Pampanga provinces, Luzon \\
\hline Ambala Ayta & Zambales, Pampanga, and Bataan provinces, Luzon \\
\hline Magbeken Ayta & Bataan Province, Luzon \\
\hline Northern Alta & Aurora Province, Luzon \\
\hline Southern Alta & Quezon Province, Luzon \\
\hline Arta & Aglipay, Quirino Province, Luzon \\
\hline Agta & Central Cagayan Province, Luzon \\
\hline Dupaningan Agta & Eastern Cagayan Province, Luzon \\
\hline Agta & Palanan and Divilacan, Isabela Province, Luzon \\
\hline Agta & San Mariano-Disabungan, Isabela Province, Luzon \\
\hline Agta & Casiguran, northern Aurora Province, Luzon \\
\hline Agta & Maddela, Quirino Province, Luzon \\
\hline Agta, Umiray Dumaget & West-central Luzon \\
\hline Agta & Alabat Island, Quezon Province, Luzon \\
\hline Rinconada Agta & Camarines Sur Province, Luzon \\
\hline Manide Agta & Camarines Norte, western Camarines Sur Province, Luzon \\
\hline
\end{tabular}




\section{Appendix B. Map of Negrito languages of the Philippines}

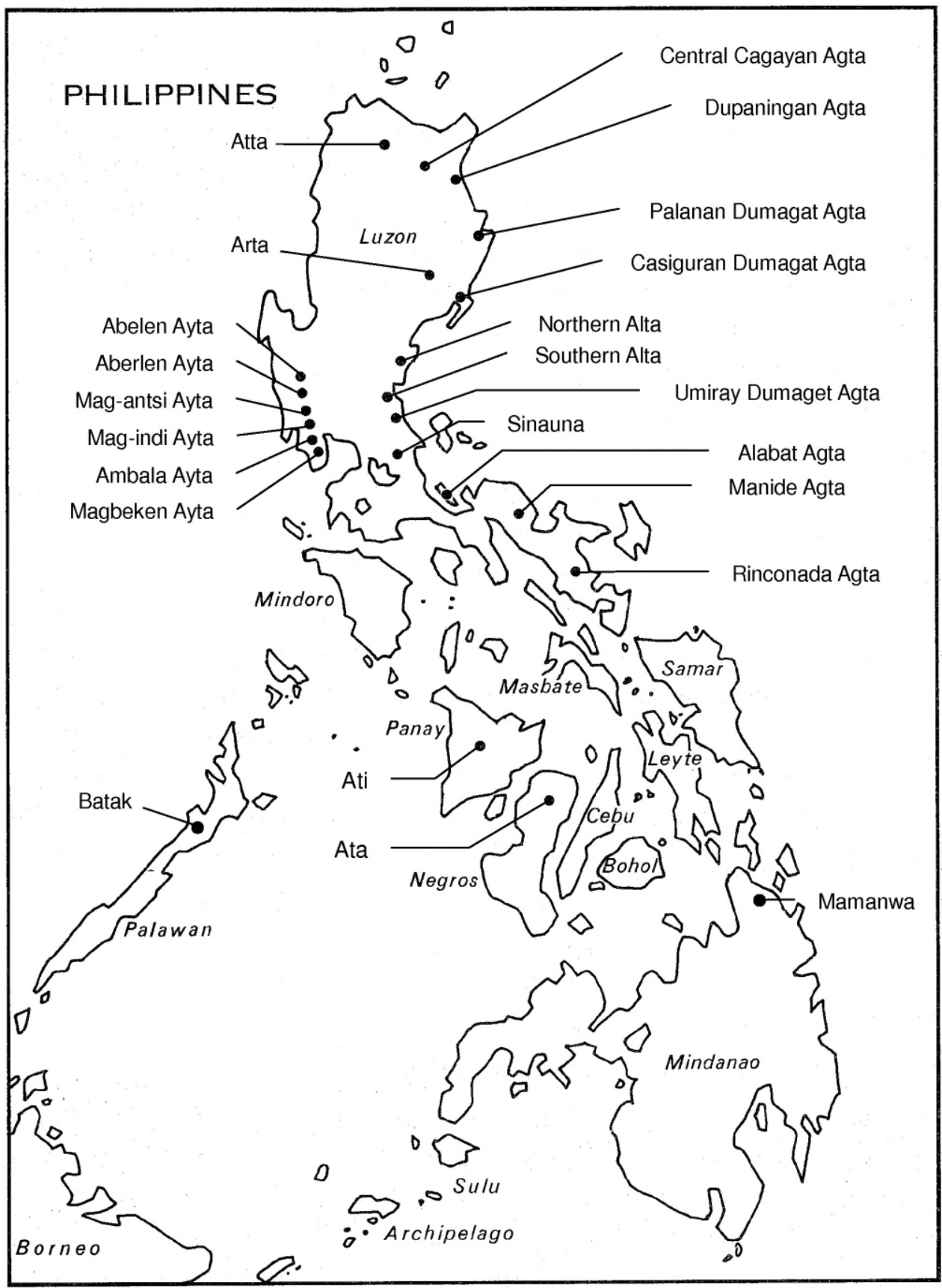



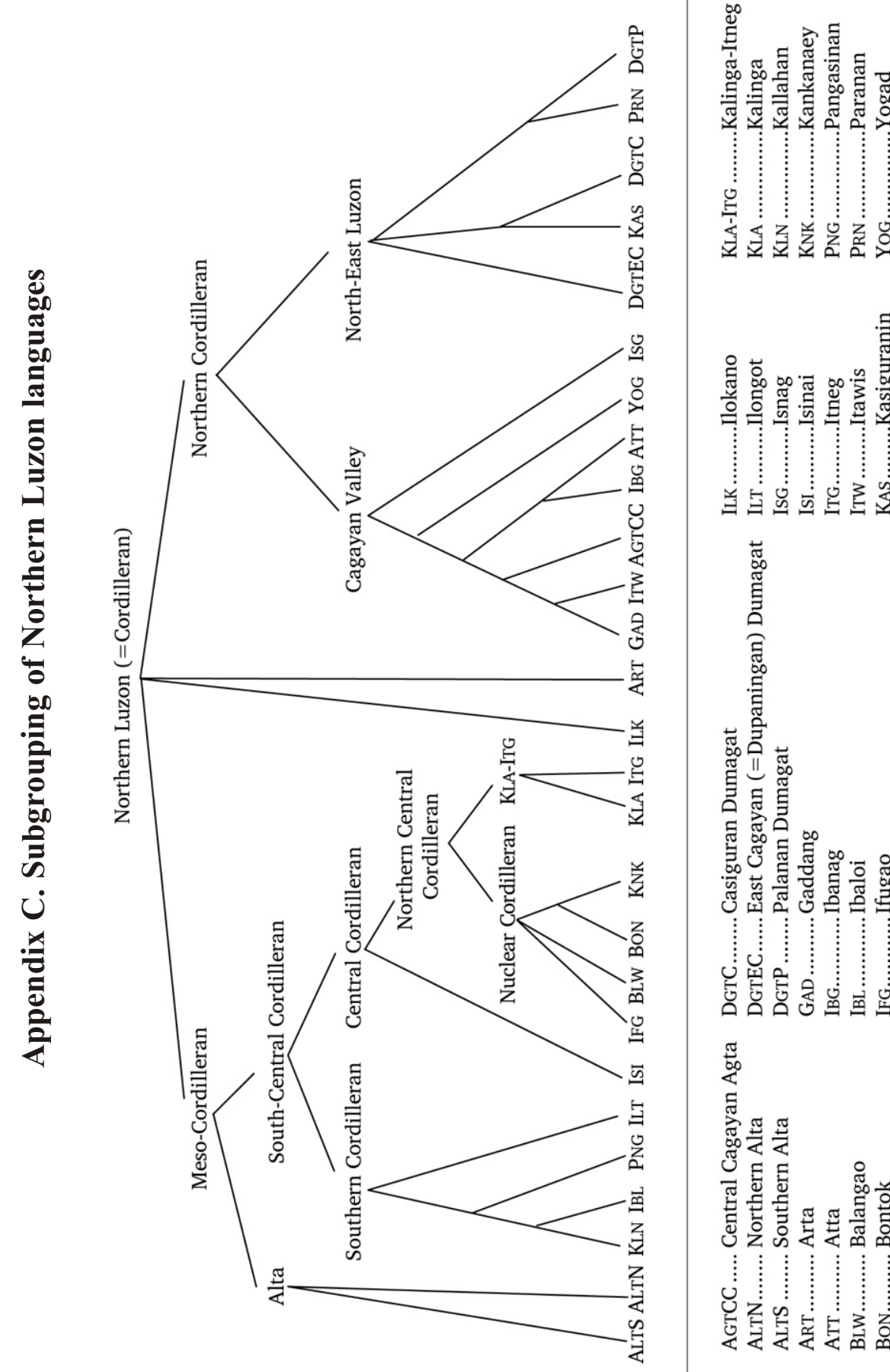

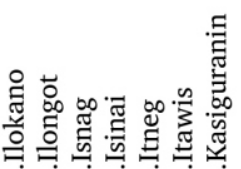

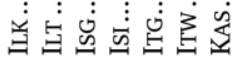

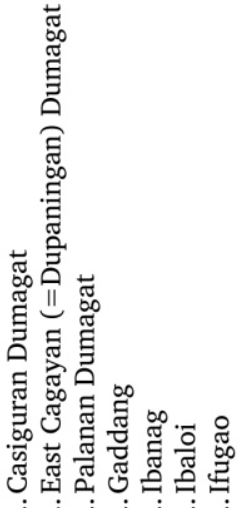

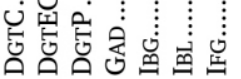

范

范

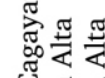

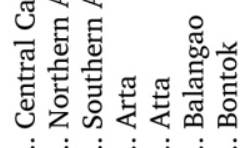

U

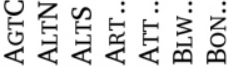




\section{References}

Antworth, Evan L. 1979. A grammatical sketch of Botolan Sambal (Philippine Journal of Linguistics Special Monograph 8). Manila: Linguistic Society of the Philippines.

Bellwood, Peter. 1985. Prehistory of the Indo-Malaysian archipelago. Sydney: Academic Press.

Bellwood, Peter, \& Eusebio Dizon. 2005. The Batanes archaeological project and the "out-of-Taiwan" hypothesis for Austronesian dispersal. Bulletin of the Indo-Pacific Prehistory Association 1(1). 1-36.

Bellwood, Peter, Janelle Stevenson, Atholl Anderson, \& Eusebio Dizon. 2003. Archaeological and palaeoenvironmental research in Batanes and Ilocos Norte Provinces, northern Philippines. Bulletin of the Indo-Pacific Prehistory Association 11. 141-161.

Blust, Robert. 1972. Note on PAN * $\mathrm{qa}(\mathrm{R})(\mathrm{CtT}) \mathrm{a}$ 'outsiders, alien people'. Oceanic Linguistics 11(2). 166-171.

Blust, Robert. 1976. Austronesian culture history: Some linguistic inferences and their relations to the archaeological record. World Archaeology 8(1). 19-43.

Blust, Robert. 1981. Variation in retention rate among Austronesian languages. Paper presented to the Third International Conference on Austronesian Linguistics, Bali, Indonesia.

Blust, Robert. 1995. The prehistory of the Austronesian-speaking peoples: A view from language. Journal of World Prehistory 9(4). 453-510.

Blust, Robert. 2005. The linguistic macrohistory of the Philippines: Some speculations. In Hsiu-chuan Liao \& Carl R. Galvez Rubino (eds.), Current issues in Philippine linguistics and anthropology: Parangal kay Lawrence A. Reid. Manila: Linguistic Society of the Philippines and SIL Philippines. 31-68.

Dempwolff, Otto. 1938. Austronesisches Worterverzeichnis: Vergleichende Lautlehre des austronesischen Wortschatzes 3 (Beihefte zur Zeitschrift für Eingeborenen-Sprachen 19). Berlin: Dietrich Reimer.

DuBois, Carl D. [1974.] Sarangani Manobo dictionary. Unpublished computer printout. Library of SIL Philippines.

Elkins, Richard E. 1968. Manobo-English dictionary (Oceanic Linguistics Special Publication 3). Honolulu: University of Hawaii Press.

Finkbeiner, Marianne. 1983. Paranan lessons. Lesson 8. Manuscript. Library of SIL Philippines.

Forster, Jannette, \& Myra Lou Barnard. [1976.] Dibabawon-English dictionary with English-Dibabawon index. Unpublished typescript. Library of SIL Philippines.

Gonzalez, Andrew. 2005. Contemporary Filipino (Tagalog) and Kapampangan: Two Philippine languages in contact. In Hsiu-chuan Liao \& Carl R. Galvez Rubino (eds.), Current issues in Philippine linguistics and anthropology: Parangal kay Lawrence A. Reid. Manila: Linguistic Society of the Philippines and SIL Philippines. 93-114.

Gordon, Raymond G., Jr. (ed.). 2005. Ethnologue: Languages of the world, 15th edn. Dallas: SIL International $<\mathrm{http}: / /$ www.ethnologue.com>. 
Hassan, Irene U., Seymour A. Ashley, \& Mary L. Ashley. 1975/1994. Tausug-English dictionary: Kabtangan iban maana, 2nd edn. (Sulu Studies 6). Jolo, Sulu: Notre Dame of Sulu College; Manila: Summer Institute of Linguistics (1st edn., Sulu Studies 4, Jolo, Sulu: Coordinated Investigation of Sulu Culture; Manila: Summer Institute of Linguistics).

Headland, Thomas N. 1975. Report of eastern Luzon language survey. Philippine Journal of Linguistics 6(2). 47-54.

Headland, Thomas N. 2002. Why Southeast Asian Negritos are a disappearing people: A case study of the Agta of eastern Luzon, Philippines. In Thomas N. Headland \& Doris E. Blood (eds.), What place for hunter-gatherers in millennium three? (Publications in Ethnography 39). Dallas: SIL International and International Museum of Cultures. 25-39.

Headland, Thomas N., \& Janet D. Headland. 1974. A Dumagat (Casiguran)-English dictionary (Pacific Linguistics C-28). Canberra: Department of Linguistics, Research School of Pacific Studies, Australian National University.

Headland, Thomas N., \& Lawrence A. Reid. 1989. Hunter-gatherers and their neighbors from prehistory to the present. Current Anthropology 30(1). 43-51.

Headland, Thomas N., \& Lawrence A. Reid. 1991. Holocene foragers and interethnic trade: A critique of the myth of isolated hunter-gatherers. In Susan A. Gregg (ed.), Between bands and states. Carbondale: Southern Illinois University Press. 333-340.

Himes, Ronald S. 2002. The relationship of Umiray Dumaget to other Philippine languages. Oceanic Linguistics 41(2). 275-294.

Magaña, Delia S. 2003. The Agta foragers in the Northern Sierra Madre Natural Park: Ancestral domains in theory and practice. In Jan van der Ploeg, Andres B. Masipiqueña, \& Eileen C. Bernardo (eds.), The Sierra Madre mountain range: Global relevance, local realities. Tuguegarao City: Golden Press. 241-257.

McFarland, Curtis D. 1980. A linguistic atlas of the Philippines (Study of Languages and Cultures of Asia and Africa Monograph Series 15). Tokyo: Tokyo University of Foreign Studies.

McKaughan, Howard P., \& Batua A. Macaraya. 1967/1996. A Maranao dictionary. Honolulu: University of Hawaii Press (2nd edn., Manila: De La Salle University Press and Summer Institute of Linguistics).

Miller, Jeanne, \& Helen Miller. 1976. Mamanwa grammar (Language Data: Asian-Pacific Series 8). Huntington Beach, CA: Summer Institute of Linguistics.

Omoto, Keiichi. 1981. The genetic origins of the Philippine Negritos. Current Anthropology 22(4). 421-422.

Paz, Victor J. 1999. Neolithic human movement to island Southeast Asia: The search for archaeobotanical evidence. Bulletin of the Indo-Pacific Prehistory Association 18(2). 151-157.

Pennoyer, F. Douglas. 1986-87. Inati: The hidden Negrito language of Panay, Philippines. Philippine Journal of Linguistics 17(2), 18(1). 1-36.

Peterson, Warren E. 1974. Summary report of two archaeological sites from north-eastern Luzon. Archaeology and Physical Anthropology in Oceania 9(1). 26-35. 
Reid, Lawrence A. 1971. Philippine minor languages: Word lists and phonologies (Oceanic Linguistics Special Publication 8). Honolulu: University of Hawaii Press.

Reid, Lawrence A. 1974. The Central Cordilleran subgroup of Philippine languages. Oceanic Linguistics 13(1-2). 511-560.

Reid, Lawrence A. 1976. Bontok-English dictionary (Pacific Linguistics C-36). Canberra: Department of Linguistics, Research School of Pacific Studies, Australian National University.

Reid, Lawrence A. 1978. Problems in the reconstruction of Proto-Philippine construction markers. In S. A. Wurm \& Lois Carrington (eds.), Second International Conference on Austronesian Linguistics: Proceedings, vol. 1 (Pacific Linguistics C-61). Canberra: Department of Linguistics, Research School of Pacific Studies, Australian National University. 33-66.

Reid, Lawrence A. 1979. Towards a reconstruction of the pronominal systems of ProtoCordilleran, Philippines. In Nguyen Dang Liem (ed.), South-east Asian linguistic studies, vol. 3 (Pacific Linguistics C-45). Canberra: Department of Linguistics, Research School of Pacific Studies, Australian National University. 259-275.

Reid, Lawrence A. 1987. The early switch hypothesis: Linguistic evidence for contact between Negritos and Austronesians. Man and Culture in Oceania [Tokyo: Japanese Society for Oceanic Studies] 3 (special issue). 41-60.

Reid, Lawrence A. 1989. Arta, another Philippine Negrito language. Oceanic Linguistics 28(1). 47-74.

Reid, Lawrence A. 1991. The Alta languages of the Philippines. In Ray Harlow (ed.), VICAL 2: Western Austronesian and contact languages: Papers from the Fifth International Conference on Austronesian Linguistics. Auckland: Linguistic Society of New Zealand. 265-297.

Reid, Lawrence A. 1992. The Tasaday language: A key to Tasaday prehistory. In Thomas N. Headland (ed.), The Tasaday controversy: An assessment of the evidence. Washington, DC: American Anthropological Association. 180-193.

Reid, Lawrence A. 1994a. Possible non-Austronesian lexical elements in Philippine Negrito languages. Oceanic Linguistics 33(1). 37-72.

Reid, Lawrence A. 1994b. Unraveling the linguistic histories of Philippine Negritos. In Thomas E. Dutton \& Darrell T. Tryon (eds.), Language contact and change in the Austronesian world (Trends in Linguistics: Studies and Monographs 77). Berlin: Mouton de Gruyter. 443-475.

Reid, Lawrence A. 1996. The Tasaday tapes. In Pan-Asiatic linguistics: Proceedings of the 4th International Symposium on Languages and Linguistics, January 8-10, 1996, vol. 5. Salaya, Thailand: Institute of Language and Culture for Rural Development, Mahidol University. 1743-1766.

Reid, Lawrence A. 1997. Linguistic archaeology: Tracking down the Tasaday language. In Roger Blench \& Matthew Spriggs (eds.), Theoretical and methodological orientations: Archaeology and language 1 (One World Archaeology 27). London: Routledge. 184-208. 
Reid, Lawrence A., \& Hsiu-chuan Liao. 2004. A brief syntactic typology of Philippine languages. Language and Linguistics [Nankang, Taipei: Institute of Linguistics, Academia Sinica] 5(2). 433-490.

Santos, Pilar C. 1975. Sinauna Tagalog: A genetic study examining its relationship with other Philippine languages. Quezon City: Ateneo de Manila University MA thesis.

Snow, Bryan E., R. Shutler, D. E. Nelson, J. S. Vogel, \& J. R. Southon. 1986. Evidence of early rice cultivation in the Philippines. Philippine Quarterly of Culture and Society 14(1). 3-11.

Tharp, James A. 1974. The Northern Cordilleran subgroup of Philippine languages. Working Papers in Linguistics [Honolulu: Department of Linguistics, University of Hawai'i] 6(6). 53-114.

Vanoverbergh, Morice. 1937. Some undescribed languages of Luzon (Publications de la Commission d'Enquête Linguistique 3). Nijmegen: Dekker \& van de Vegt.

Wolff, John U. 1972. A dictionary of Cebuano Visayan, 2 vols. (Data Paper 87). Ithaca, NY: Southeast Asia Program, Cornell University.

Zorc, R. David. 1974. Internal and external relationships of the Mangyan languages. Oceanic Linguistics 13(1-2). 561-600.

Zorc, R. David. 1979. Core etymological dictionary of Filipino, fascicle 1. Batchelor, Northern Territory, Australia: Public Domain.

Zorc, R. David. 1993. The prehistory and origin of the Tagalog people. In Øyvind Dahl (ed.), Language - a doorway between human cultures: Tributes to Dr. Otto Chr. Dahl on his ninetieth birthday. Oslo: Novus. 201-211. 